\title{
The Distance of Heaven: An Analysis of the Guodian Wu Xing
}

\author{
Matthew James HAMM*
}

\begin{abstract}
This paper argues that the Guodian Wu Xing consists of two interrelated sections that reflect its distinction between goodness (a characteristic of humans) and virtue (a trait of Heaven). Individually, each section emphasizes different aspects of self-cultivation. When read against one another, they articulate the text's main argument that Heaven is a distant figure and that the sage, a figure who understands the Way of Heaven, is almost unreachable. As such, the text focuses on the gentleman, a figure who achieves virtue (defined as timeliness) within a dispositional context by emulating Heaven in accordance with the Way of the Gentleman.
\end{abstract}

Keywords: Guodian $W u$ Xing, virtue, goodness, heaven, timeliness

\section{Oddaljenost neba: Analiza Guodian Wu Xing-a}

\section{Izvleček}

Ta članek zagovarja trditev, da je Guodian Wu Xing sestavljen iz dveh medsebojno povezanih delov, ki izražata razlikovanje med dobroto (značilnost ljudi) in vrlino (lastnost neba). Vsak del posamično poudarja različne aspekte samo-kultivacije. Ko ju beremo vzporedno, se nam jasno izoblikuje osnovna trditev besedila, namreč da je nebo oddaljena podoba in da je modrec kot osebek, ki razume pot neba, skoraj nedosegljiv. Besedilo se tako osredotoča na plemenitnika, osebo, ki dosega vrlino (definirano kot pravočasnost) znotraj razpoložljivega konteksta, posnemajoč nebo v skladu s potjo plemenitega.

Ključne besede: Guodian Wu Xing, vrlina, dobrota, nebo, pravočasnost

* Matthew James HAMM, PhD Candidate in East Asian Languages and Civilizations, Harvard University, United States.

mhamm[at]fas.harvard.edu

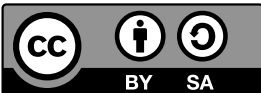




\section{Introduction}

Excavated in the village of Guodian 郭店 in Hubei 湖北 province in 1993, the Wu Xing 五行 or The Five Conducts, has given rise to a range of interpretations, most of which analyse the text with reference to other works and by situating it within broader contexts.

Most immediately, the work has frequently been read alongside the Wu Xing manuscript discovered at Mawangdui 馬王堆 in Hunan 湖南 province in 1973. Based on a variety of factors, including perceived resemblances between the two texts and the Mengzi 孟子, many scholars have interpreted the two manuscripts together as key components in the reconstruction of the Si-Meng 思孟 scholastic lineage, described by Pang $\mathrm{Pu}$ as part of the greater internalist branch of Confucian thought (Pang 1998, 89). ${ }^{1}$ Other scholars, accepting or rejecting this historical narrative to varying degrees, have analysed the Guodian text with respect to larger ideas, such as early Chinese moral and aesthetic theory, the work's relationship to the competing theories of the Mengzi and the Xunzi 荀子, $r u$ 儒 virtue discourse, arguments regarding the worldview of the Guodian strips, and strategies of argumentation in the Warring States period. ${ }^{2}$

In order to supplement this body of research, the present study focuses exclusively on the Guodian Wu Xing, analysing it based only on its internal content and structure. ${ }^{3}$ This approach yields a different interpretation of the text and suggests that it is best read as two discontinuous but related essays that reflect the work's basic division of goodness (shan 善), the harmony of four of the eponymous conducts, and virtue ( $d e$ 德), the harmony of all five conducts. These two sections mirror one another in structure, but focus on different conducts and themes. Consequently, investigating parallel passages across the text reveals each section's most basic concerns.

The goodness section emphasizes active engagement with the world, goodness as an inherent feature of imperfect humans, and describes the partial state in which humans begin self-cultivation. Its detailed description of the conducts also reveals

1 Two of the most influential articulations of this view may be found in Li 1998 and Pang 2000. However, this viewpoint has been generally accepted in most scholarship in mainland China, for which Chen Lai provides a helpful overview (Chen 2012).

2 See Cook 2000, Ikeda 2003, Csikszentmihalyi 2004, Holloway 2009 and Meyer 2012, respectively.

3 The exception to this is that I have followed scholars such as Scott Cook who have used the Mawangdui Wu Xing to assist their transcriptions of the Guodian manuscript. However, the differences between the two manuscripts are primarily conceptual rather than linguistic and are based on their different textual structures as well as the addition of the commentarial section in the Mawangdui manuscript. This makes the use of the Mawangdui text for reconstructive purposes relatively unproblematic. 
that they are not discrete entities that cause one another, but domains of related dispositions and behaviours.

The virtue section focuses on contemplative methods for developing the related conducts and depicts the unified endpoint of self-cultivation. This endpoint is the complete harmonization of the five conducts so that they may be endlessly recombined in order to appropriately respond to any given situation. This timely harmony is the definition of virtue, which is a trait of Heaven (tian 天). ${ }^{4}$

However, when read together, these two sections argue that Heaven will always remain a distant figure and that the ideal of the sage (shengren 聖人), a figure who understands the Way of Heaven (tiandao 天道), is so elusive as to be almost unobtainable. Therefore, the text focuses its attention on the gentleman (junzi 君 子), an imperfect but more achievable goal. The two sections provide the necessary context to understand how the gentleman might reach a state of virtue by emulating Heaven in accordance with the Way of the Gentleman (junzidao 君子道). Ultimately, the text's program of self-cultivation aspires to this Wa-not because it is ideal, but because it is within reach.

\section{Opening Summary of the Text}

The Wu Xing begins by discussing the formation of five qualities and the effects of their formation:

仁形於內謂之德之行, 不形於內謂之行。

When benevolence takes form within, it is called "virtuous conduct".

When it does not take form within, it is called "conduct". 5

The difference between these two types of conduct lies in whether or not the quality of "benevolence" (ren 仁) has taken form within. This formula is repeated for the four other qualities: "righteousness" ( $y i$ 義), “ritual propriety" ( $l i$ 禮),

$4 \quad$ Although tian can refer to the sky or the heavens, in the Wu Xing, as in many texts of the period, it refers to the principal deity of the time.

5 Strip 1. Unless otherwise noted, all translations are my own but I have benefited greatly from the excellent translations of Scott Cook, Mark Csikszentmihalyi, Dirk Meyer and Kenneth Holloway. The transcription follows the conclusions of Scott Cook (Cook 2012, 46-520). The strip numbering follows that set out by the editors of the Guodian Chumu Zhujian 郭店楚墓竹簡 (The Bamboo Strips of the Chu Tomb of Guodian) (Jingmenshi Bowuguan, 1998). For photographs of the manuscript and the editors' original transcription and notes see Jingmenshi Bowuguan 1998, $29-36 ; 147-54$. 
“knowledge" ( $z h i$ 智) and "sagacity" (sheng 聖). ${ }^{6}$ The work thus provides a definition for the five conducts: they are modes of action distinguished by their moral greatness (virtuousness) and comprising both internal qualities (that take form within) and external qualities in the form of action. The combined nature of the conducts suggests that the boundary between the internal and external is a porous one. ${ }^{7}$ As Scott Cook remarks, the concern is with "morality put into actual practice" (Cook 2000, 122).

Based on the conducts' internal formation, Mark Csikszentmihalyi has argued that the chief concern of the text is sincerity, and that it seeks to provide a physiological basis to distinguish between "authentic and inauthentic moral actions" as part of an effort by followers of Confucius to meet the accusation that "their actions were hypocritical and their performance of ritual was hollow" (Csikszentmihalyi 2004, 59).

Though there is nothing in the text to preclude the importance of sincerity, the fact that it distinguishes between “virtuous conduct" (dezhixing 德之行) and simply “conduct" (xing 行), rather than a more pejorative term, suggests that the distinction is between ethically ineffective behaviour versus behaviour that is morally efficacious. As such, the primary issue is not authenticity but a moral greatness (virtuousness) that the text will later define as a timely responsiveness. ${ }^{8}$ This is supported by the fact that virtue is achieved by harmonizing the five conducts that have taken form within:

德之行五, 和謂之德, 四行和謂之善。

善, 人道也。德, 天道也。

The virtuous conducts are five. When they are in harmony it is called "virtue".

When the four conducts are in harmony it is called "goodness".

Goodness is the Way of Humans. Virtue is the Way of Heaven. ${ }^{9}$

While each conduct may be considered virtuous in and of itself, virtue (associated with the Way of Heaven) can only be achieved by harmonizing all five conducts

6 Sagacity is the one exception to this pattern as the text reads, "when it does not take form within, it is called virtuous conduct". Because the text pays a great deal of attention to developing sagacity internally, I concur with Cook that this is likely a scribal error, although it remains a subject of much debate (Cook 2012, 486 n.8.).

7 The text emphasizes this by using the same graphs to indicate both the internal qualities and as a shorthand for each conduct as a whole.

8 Although it differs in the details, Csikszentmihalyi's argument for sincerity is broadly compatible with Scott Cook's (Cook 2000).

9 Strips 4-5. 
together. The result of harmonizing only four of them is a state of goodness, ${ }^{10}$ which is associated with the Way of Humans (rendao 人道). Though virtue is superior to the state of goodness, the two are not radically distinct, as virtue builds atop goodness by adding the conduct of sagacity to the other four conducts and harmonizing the result. How to achieve this feat is the key concern of the text. (Puett 2010, 56)

The text emphasizes the distinction between virtue and goodness by reflecting it in its structure. From strip one through to the end of strip twenty-nine all five conducts appear. However, beginning with strip thirty (and after a significant structural break), only four of the conducts are discussed and sagacity does not reappear for the remainder of the work. This suggests that the text is not a single, continuous essay but rather two separate but interrelated discussions, the first describing virtue and the second describing goodness.

The overall textual structure, therefore, consists of an opening summary (strips one through five) followed by a description of virtue (strips five through twenty-nine) and concludes with a discussion of goodness (strips thirty through fifty). For the sake of clarity, I will discuss the two sections in reverse, beginning with goodness and ending with virtue.

\section{The Goodness Section}

The two sections do not discuss all five conducts equally. Instead, they mirror one another by first discussing three conducts and then focusing on the relationship of two conducts in depth. The second section on goodness first discusses benevolence, righteousness and ritual propriety before turning to the interplay of benevolence and righteousness.

10 Franklin Perkins suggests that the "four conducts" (sixing 四行) refer to those which do not take form within, in contrast to the five "virtuous conducts" which do (Perkins 2014, 505-6). While this reading is provocative it does not take into account those instances in which the term "five conducts" (wuxing 五行) is used in apparent reference to the virtuous conducts (strips 1, 6 and 29). These instances suggest that the phrasing of sixing does not differentiate types of conducts but is characteristic of the fluid writing style of the text already mentioned in note 6. Perkins' reading of the term "conduct" as moral action is shared by scholars such as Pang Pu (Pang 2000), Chung-ying Cheng (Cheng 2010), Wang Qinling (Wang 2015) and Wang Miquan (Wang 2016). It is also similar to the arguments of Mark Csikszentmihalyi and Scott Cook mentioned above, insofar as they are all part of the trend among scholars to read the Wu Xing according to an internalist/externalist framework. According to this framework, the work's primary focus is thought to be a properly internal morality (virtue) that allows for spontaneous and perfect ethical actions as opposed to simply complying with external norms or acting out of conscious deliberation (goodness). 
As Michael Puett notes, the text explains how to develop these conducts using a repeated pattern that is characterized by chains of "emotional dispositions, each of which is to be balanced by another disposition, thus leading to a development toward yet another disposition" (Puett 2010, 56). Each chain ultimately results in the formation of a specific conduct. These passages not only explain how the different conducts are formed, but also provide clues as to their nature:

顔色容貌溫, 勉。以其中心與人交, 悅也。

中心悅, 播遷於兄弟, 戚也。戚而信之, 親也。

親而篤之, 愛也。愛父, 其繼愛人, 仁也。

To have a countenance and outward appearance that is warm is to be encouraging.

To interact with other people by means of one's inner heart-mind is to be delighted.

When one's inner heart-mind is delighted and one spreads and disperses it to one's older and younger brothers one is affectionate.

To be affectionate and make it trustworthy is to be intimate.

To be intimate and make it earnest is to cherish.

To cherish one's father and, in turn, to cherish other people is to be benevolent. ${ }^{11}$

As Edward Slingerland notes, this passage "describes the gradual expansion of kin-based affection to encompass benevolence toward non-kin" (Slingerland $2008,252)$. The key point of this process is that it is accomplished by intimacy, as one must use one's inner heart-mind (zhongxin 中心) to engage in it. In practicing benevolent behaviour, a person not only shares their inner feelings with their family but also acts upon those feelings, changing and intensifying them before spreading them to others.

A important aspect of this process is the apparent jump from being "encouraging" (mian 勉) to being "delighted" (yue 悅). While it is clear that each of the subsequent steps relates to one another causally, there is no connection between the first two stages, though they are thematically similar. This point will be dealt with in more detail below. Here it is sufficient to note that the passage does not provide an exact blueprint for developing benevolence or a precise definition of it. Instead, it associates it with a suite of related dispositions pertaining to affection, happiness and intimacy.

The text goes on to describe righteousness as follows:

11 These three passages (strips to 32-37) immediately follow the opening passage of the goodness section (30-32), which is discussed below. 
中心辯然而正行之, 直也。直而遂之, 肆也。 肆而不畏強禦, 果也。不以小道害大道, 簡也。

有大罪而大誅之, 行也。貴貴, 其等尊賢, 義也。

When one's inner heart-mind discriminates it to be thus and one correctly enacts it, one is upright.

To be upright and follow it is to be unreserved.

To be unreserved and not be in awe of despots is to be successful.

To not, by means of small ways, harm the great Way is to be simple.

To have a great crime and greatly punish it is to enact.

To value the noble, and to respect the worthy according to their level is righteousness.

Like benevolence, righteousness is based on the inner heart-mind. However, unlike the familial interaction of benevolence, righteousness arises from the cogent recognition of moral and hierarchical distinctions. Decisively acting upon these distinctions seems to take place more in the public realm as opposed to the domestic sphere, and righteousness is, therefore, defined as a counterpoint to benevolence. ${ }^{12}$

Importantly, this passage contains even more causal gaps than the one preceding it. In particular, "to be simple" (jian 簡) and "to enact" (xing 行) are presented in a related, rather than a causal, fashion, and neither is directly linked to righteousness or the preceding steps.

The theme of out-group interaction continues in the description of ritual propriety:

以其外心與人交, 遠也。遠而莊之, 敬也。

敬而不解, 嚴也。嚴而畏之, 尊也。

尊而不驕, 恭也。恭而博交, 禮也。

To interact with others by means of the outer heart-mind is to be distant.

To be distant and make it solemn is to be respectful.

To be respectful and not slacken is to be stern.

To be stern and make it awe-inspiring is to be honoured.

To be honoured and not be arrogant is to be humble.

To be humble and interact widely is to be ritually proper.

Ritual propriety is concerned with the successful maintenance of hierarchical distinctions. Uniquely, it is rooted in the outer heart-mind (waixin 外心) and arises from the preservation of a proper distance between oneself and others that

12 This notion is explored in more detail on strips $37-42$, where it is implied that the correct combination of the two conducts is the key to effective judicial action. 
ultimately leads to a state of appropriate humility. Unlike the other two conducts, its development contains no causal gaps but is a linear process in which related dispositions are folded into one another and intensified.

An important common element of these three passages is that they all involve active engagement with the external world. These conducts are not formed or practiced entirely within the individual, but are dependent on the interaction of the self with others.

These passages are expanded forms of truncated chains that appear in the virtue section of the text, one example of which is the chain of righteousness:

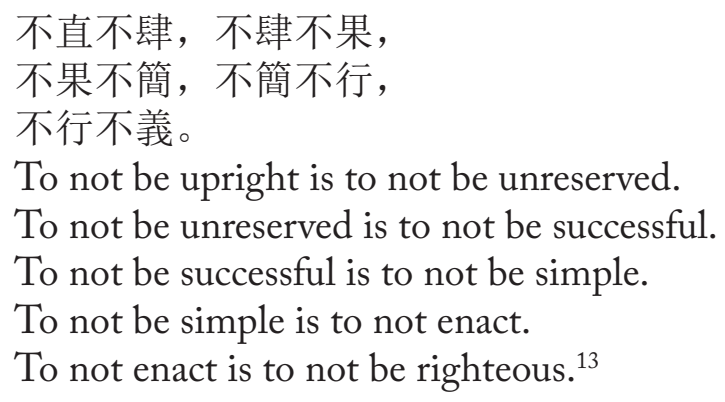

To not be unreserved is to not be successful.

To not be successful is to not be simple.

To not be simple is to not enact.

To not enact is to not be righteous. ${ }^{13}$

Here, the same key terms are presented in the same sequence as in the expanded discussion above. However, by obscuring the details of the linkages between the various terms the text gives the appearance that they are produced through strict, linear causation. This presentation even extends to the interactions between the conducts themselves. For example, the goodness section begins with the following summation:
見而知之, 智也。知而安之, 仁也。
安而行之, 義也。行而敬之, 禮也。
To see and understand it is to be knowledgeable.
To understand and be at peace with it is to be benevolent.
To be at peace with and enact it is to be righteous.
To enact and respect it is to be ritually proper. ${ }^{14}$

This passage appears to be a generative sequence in which each conduct builds on the one that preceded it and causes the next. However, the text's recurrent presentation of a linear system is problematic, because it contains a number of

13 These truncated chains (strips 21-22) summarize elements of goodness in order to demonstrate its presence within the state of virtue.

14 This passage and the lines discussed below appear on strips 30-32. 
inconsistencies. These include the causal gaps in the conduct passages noted above, as well as instances in which elements of a given causal chain appear in another causal chain but in a different order..$^{15}$ Moreover, each of the conducts is defined in the above passage, but these definitions do not match others given in the text. Such inconsistencies undermine the structured system that the text presents, and have given rise to different interpretations of the work's meaning.

Dirk Meyer, for instance, reads the above passage as describing the development of the conducts. Because of the causal contradictions present in the text, he argues that what is being discussed is a "paradox of self-cultivation", in which "realising any of the five virtues simultaneously depends on the accomplished cultivation of the other virtues", and that the solution "lies in a human's awareness ( $z h i$ 知) of possessing the five virtues within him" (Meyer 2012, 128). Consequently, the system of the text is linear and causal, but in a circular and, therefore, paradoxical sense. ${ }^{16}$

By contrast, Michael Puett argues that the "proliferation of series of interlocking chains" and the fact that "there is no consistent definition given to any of the terms" means that in every situation one is "modulating each type of action by bringing it into play with the other types of actions", so that each "is relevant only insofar as it is modulated by and harmonized with each of the others" (Puett 2010, 57). Accordingly, apparently causal depictions of the conducts or their formation are descriptions of harmonious interactions and not linear generation.

That one can understand the relatedness of the concepts present in the above three conduct passages despite their causal gaps is suggestive of this latter reading. In them, the text is not presenting a sequential process in which each trait leads successively to the formation of an ultimate conduct. Instead, it is describing a scheme in which the conducts may best be understood as domains of similar traits. Therefore, one forms the conducts by successfully bringing together and deepening groups of related dispositions and behaviours. These dispositions could cause one another but need not do so in a set order, and thus the source dispositions and their results could be interchangeable.

Consequently, the summary passage above does not describe how the conducts form one another as discrete, metaphorical objects, but how they might act together in concert as domains of related dispositions. According to such a reading, the names of each conduct would be understood as shorthand references to

15 For example, the chains on strips 6 and 13 present opposite orderings of "to be delighted" and "to be at peace" (an 安).

16 Although Meyer's idea of the paradox of self-cultivation within the Wu Xing is relatively unique, his linear and causal reading of the conducts is representative of most scholarship on the text. 
broader domains, and one's response (such as "being at peace") would indicate what particular domain one was drawing upon. The result is a fluid system in which the various conducts might be rearranged in different orders-something that would not be permitted in a fixed, linear model.

The implication of this is that while the summary passage demonstrates how four of the conducts interact as responses to a shared object, this image is partial at best. The Wu Xing can never present a fully systematic and complete view of the world, because it "posits a world of endless work" in which one strives to achieve harmony, a goal that "is at best a brief occurrence" (Puett 2010, 57).

The text concludes the summary passage with a description of this ephemeral harmony:

和則同，同則善。

If (the four conducts) are in harmony then there is uniformity, if there is uniformity then there is goodness.

When the four conducts are in harmony they are in a state of uniformity (tong 同), which is further understood as a state of goodness that is, by definition, incomplete. The text explains that this deficiency is an inherent part of human nature by presenting the following explanation of our internal workings:

耳目鼻口手足六者, 心之役也。

The ears, eyes, nose, mouth, hands and feet are six. They are the heartmind's servants. ${ }^{17}$

The text then details how no part of the body can resist the heart-mind's mastery and concludes with a telling description of the harmony that it enforces:

和則同，同則善。

If (the six) are in harmony then there is uniformity, if there is uniformity then there is goodness. ${ }^{18}$

This harmony is described in the same terms as that of the four conducts, implying that there is an unknown, missing element to this internal scheme. This presentation fully explicates the text's statement that "goodness is the Way of Humans". Goodness, the harmonization of an incomplete set of elements, is an inherent characteristic of human beings, and achieving it with respect to the four

$17 \quad$ Strip 45.

18 Strip 46. 
conducts means to accord with the manner in which human beings exist (the Way of Humans).

Furthermore, achieving even an incomplete harmonization of the conducts is not a certain prospect:

聞道而悅者, 好仁者也。聞道而畏者, 好義者也。

聞道而恭者, 好禮者也。聞道而樂者, 好德者也。

One who hears the Way and is delighted is one who loves benevolence.

One who hears the Way and is in awe is one who loves righteousness.

One who hears the Way and is humble is one who loves ritual propriety.

One who hears the Way and is joyful is one who loves virtue. ${ }^{19}$

In this, the last passage of the text as a whole, the Wu Xing presents a typology of individuals based on their reaction to hearing the Way without understanding it. ${ }^{20}$ The type of reaction a person has inclines that person toward one of the conducts more than the others. Because different people exist in varying states of inherent imbalance they must develop other aspects of themselves to achieve a harmony of the conducts. The text thus concludes by positing the beginning point of self-cultivation, which, if it accords with the Way of Humans, will be only partially successful. However, the person who loves virtue points away from this tragic possibility toward the higher state described in the virtue section, as discussed below.

\section{The Virtue Section}

Like its counterpart, the virtue section discusses the formation of three conducts (benevolence, knowledge and sagacity) in detail before investigating two (knowledge and sagacity) in greater depth. Their formation is described in three passages which parallel those found in the goodness section, but focus on the notion of “contemplation" ( $s i$ 思). As before, these passages begin with benevolence:

仁之思也清, 清則察, 察則安, 安則溫, 溫則悅,

悅則戚, 戚則親, 親則愛, 愛則玉色,

玉色則形，形則仁。

When one contemplates benevolence, one is pure.

If one is pure then one examines, if one examines then one is at peace.

If one is at peace then one is warm, if one is warm then one is delighted.

19 Strips 49-50.

20 Since this Way is "heard" (wen 聞), it is likely to be the Way of the Gentleman discussed below. 
If one is delighted then one is affectionate, if one is affectionate then one is intimate.

If one is intimate then one cherishes, if one cherishes then one has jade colouration.

If one has jade colouration then it takes form, if it takes form then one is benevolent. ${ }^{21}$

Here the text discusses how to form benevolence by first contemplating the idea of it, which triggers a series of affective changes in one's thoughts. ${ }^{22}$ Following these changes through to the end of the process results in a "jade colouration" and benevolence taking form.

This process of developing the conducts through individual contemplation continues with knowledge and sagacity:

智之思也長, 長則得, 得則不忘,

不忘則明，明則見賢人，

見賢人則玉色, 玉色則形, 形則智。

When one contemplates knowledge one is long-lasting.

If one is long-lasting then one obtains, if one obtains then one does not forget.

If one does not forget then one is perspicacious, if one is perspicacious then one sees the Worthy Person.

If one sees the Worthy Person then one has jade colouration, if one has jade coloration then it takes form, if it takes form then one is knowledgeable.

聖之思也輕, 輕則形, 形則不忘,

不忘則聰，聰則聞君子道，

聞君子道則玉音，玉音則形，形則聖。

When one contemplates sagacity one is light.

If one is light then it takes form, if it takes form then one does not forget.

If one does not forget then one is acute, if one is acute then one hears the Way of the Gentleman.

If one hears the Way of the Gentleman then one has a jade tone, if one has a jade tone then it takes form, if it takes form then one is sagacious.

21 This passage and the two subsequent passages occur on strips 12-16.

22 Mark Csikszentmihalyi provides a fascinating discussion of what the terms in these passages might entail, and argues that the "jade colouration" (yuse 玉色) and “jade tone” (yuyin 玉音) are physiological manifestations of moral development, indicative of the Wu Xing's "embodied moral psychology" (Csikszentmihalyi 2004, 73-78). 
These two passages are written in parallel with one another, reflecting the complimentary perceptual nature of the two conducts. Knowledge is associated with visual clarity or perspicacity (ming 明), the ability to see the Worthy Person (xianren 賢人) and, like benevolence, the visible sign of jade colouration. Sagacity, on the other hand, is linked with aural clarity or acuity (cong 聰), the ability to hear the Way of the Gentleman and, uniquely, is marked by a jade tone. Elsewhere in the text, knowledge and sagacity are repeatedly defined as including both the perception and understanding of their respective objects. ${ }^{23}$

Because these three passages all use the term "to take form" (xing 形), they appear to be describing how the conducts "take form within," as described in the opening of the text. Since only three conducts are described the explanation would appear incomplete. However, when paired with the parallel portion of the goodness section it becomes clear that the text is differentiating between different types of conducts.

Righteousness and ritual propriety are those conducts that can be developed primarily through external engagement with the world. By contrast, knowledge and sagacity are developed through contemplation. Though one set of conducts is socially active and the other contemplative, we cannot say that they lie on either side of a rigid barrier between the internal and external. Righteousness and ritual propriety incorporate internal, emotional elements, while one could easily argue that the Worthy Person and the Way of the Gentleman are external objects. As such, the two pairs differ in whether they focus on the internal or the external, but do not adhere to either absolutely. Such an ambiguity might account for why benevolence falls into both categories, capable of being developed through both engagement and contemplation, and thus bridging the two classes.

By including internal and external elements in both sections, the text clarifies that the state of virtue is not superior because it is based on an internal moral root or a balance of internal and external sources of morality, but rather because it is a complete harmony that incorporates the fifth conduct of sagacity:

聞君子道, 聰也。聞而知之, 聖也。

聖人知天道也。

知而行之, 義也。行之而時, 德也。

To hear the Way of the Gentleman is to be acute.

To hear and understand it is to be sagacious.

The sage understands the Way of Heaven.

To understand and enact it is to be righteous.

To enact it and be timely is to be virtuous. 
見賢人, 明也。見而知之, 智也。

知而安之, 仁也。安而敬之, 禮也。

To see the Worthy Person is to be perspicacious.

To see and understand them is to be knowledgeable.

To understand and be at peace with them is to be benevolent.

To be at peace with and respect them is to be ritually proper. ${ }^{24}$

Here, in a manner similar to the goodness section, the text presents two discontinuous and partial portrayals of how the conducts interact with one another, this time presenting all five conducts across the two sections. That the two passages each display only a subset of the conducts interacting reinforces the text's non-systematic worldview, which becomes sensible when the conducts are understood as domains of associations.

For example, although the sequence is slightly different, each conduct is associated with the same idea as in the goodness section's summary passage. These associations further clarify that the different chains of conducts represent the variable interaction of different families of dispositions, rather than causal sequences of discrete entities. By presenting the combinations as reactions to different perceptual objects (the Way of the Gentleman and the Worthy Person) these passages also emphasize the idea that the harmonious interaction of conducts is situational: different combinations will be appropriate to different circumstances.

Fittingly, it is in this context that the text adds to its definition of virtue, describing it as acting in a manner that is "timely" (shi 時). This definition explains why only four conducts would fail to produce such a state. A virtuous, timely individual would be able to respond with the appropriate conduct or combination of conducts in any given situation. However, if a person had only developed and harmonized four such conducts there would inevitably be instances that they could not respond to, resulting in a loss of harmony. This difference articulates the text's initial distinction between "virtuous conduct" and mere "conduct."While "conduct" refers to those actions that are not timely, each of the five conducts is virtuous because it can be the correct response to a given situation and may be harmonized with the other four to produce a unified and responsive virtuous state. It is this timely responsiveness that forms the Wu Xing's idea of moral greatness.

This definition of virtue also explicates the association between virtue and the Way of Heaven. Just as goodness is an inherent aspect of humans, so too must virtue, understood as timeliness, be an inherent characteristic of Heaven and how

24 These passages and the concluding lines below are on strips 26-30. 
it operates. Furthermore, it is a characteristic that humans can emulate through virtuous behavior.

The virtue section concludes with summary lines that parallel those found in the goodness section:

和則樂，樂則有德，有德則邦家譽。

文王之視也如此。

「文王在上，於昭于天」，此之謂也。

If (the five conducts) are in harmony then one is joyful. If one is joyful then one has virtue. If one has virtue then the states and families will praise (one).

The vision of King Wen was like this.

"King Wen resides above, how bright he is in Heaven!" This refers to it.

Here, the text utilizes the same pattern as the goodness section, but differentiates virtue by replacing "uniformity" with "joy” (le 樂). Mark Csikszentmihalyi points out that the character le can also be read as yue with the meaning of "music", and argues that this "is used as an unstated philosophical argument" (Csikszentmihalyi 2004,169$)$. In this case, the double meaning depicts virtue as a metaphorical symphony in which the different notes of the conducts are harmonized in a timely and joyful way. ${ }^{25}$

The image of King Wen in this passage mirrors the ending of the goodness section. That passage describes four different types of people, demonstrating the beginning of self-cultivation. Here the text describes only one person, King Wen, who appears as the end goal of self-cultivation. Together, the two passages demonstrate that self-cultivation begins with multiplicity and partiality, but ends with unity and harmony, embodied in the singular figure of King Wen who stands radiant alongside Heaven.

A further significance of this imagery is that it implies that even at the highest levels of self-cultivation there remains a distinction between humans and Heaven. Although humans can emulate the timeliness of the Way of Heaven through virtuous conducts they cannot become Heavenly. Heaven remains a figure apart, and the distance between it and humans is exacerbated by the description of the sage in the above section: "the sage understands the Way of Heaven" (shengren zhi tiandao ye 聖人知天道也). This is the only occurrence of the sage in the entire

25 Scott Cook artfully captures this notion of a virtuous symphony with his elegant translation of $d e$ as "virtuosity". and provides a fascinating analysis of how music relates to the highest moral state (Cook 2000). 
text, and its striking appearance breaks the otherwise perfect parallelism of the two summary passages, as well as the goodness summary passage that follows them.

Some scholars have downplayed this breakage. For instance, Mark Csikszentmihalyi suggests that it might represent "misplaced commentary" (Csikszentmihalyi 2004,297). By contrast, Chung-ying Cheng reads the passage as a continuous narrative in which the sage understands the Way of Heaven and puts it into practice through righteousness so as to develop ritual (Cheng 2010, 154). However, the strategic placement of this break after the discussion of sagacity and its disruption of the passages' parallelism seems to suggest that it is a deliberate rhetorical move meant to emphasize the distinction between sagacity and the sage. One who has cultivated the conduct of sagacity understands the Way of the Gentleman, but the sage has access to a higher level of understanding altogether. ${ }^{26}$

This understanding also marks the sage as an elusive ideal. At no other point is "understanding the Way of Heaven" described as being possible, nor is any advice given as to how one might attempt such a feat. The parallel break illustrates that the sage is wholly outside of the text's system, appearing and disappearing without explanation. Moreover, while the sage understands the Way of Heaven he is still not portrayed as Heavenly, suggesting that there remains an element of distance between the figure and Heaven itself. ${ }^{27}$ Thus, in the system of the Wu Xing, Heaven is an unreachable figure and the sage (although not necessarily a perfect ideal) is so elusive as to be almost unobtainable. Faced with this seemingly tragic picture, the text turns away from it and instead focuses its attention on the gentleman, a figure less advanced than the sage but more achievable.

\section{The Figure of the Gentleman}

In keeping with its division of goodness and virtue, the text presents two modes in which the gentleman might operate, summarizing this distinction in the virtue section:

君子之為善也, 有與始, 有與終也。 君子之為德也, 有與始, 無與終也。

26 Dirk Meyer has suggested that this is a common rhetorical feature in early China, referring to it as "principal insertion", though he argues that the statement is more compatible with the remainder of the passage (Meyer 2012, 116-7).

27 For representative studies that argue for a much tighter linkage between Heaven and humanity see Pang 2000, Ikeda 2003, Csikszentmihalyi 2004 and Li 2015. 
When the gentleman practices goodness, he has that with which he begins and that with which he ends.

When the gentleman practices virtue, he has that with which he begins but lacks that with which he ends. ${ }^{28}$

The text divides the gentleman into two types, the gentleman of goodness and the gentleman of virtue, and discusses them in the goodness and virtue sections, respectively. Consequently, the portrayal of the gentleman in each section reflects the dominant themes associated with that section.

In the above passage, the division between the two types echoes that seen in the summary passages on goodness and virtue. Having achieved only an incomplete harmony, the gentleman of goodness would inevitably encounter situations he could not respond to, and so his harmonized responses would come to an end. By contrast, the gentleman of virtue would be able to endlessly respond to all situations with the appropriate combination of conducts, thus marking him as the goal of the text's self-cultivation program..$^{29}$ By examining the two presentations of the gentleman we can see how the gentleman of goodness might become the greatest version of himself.

The first of half of the text's description of the gentleman of goodness reads as follows:

君子集大成。

能進之為君子, 弗能進也, 各止於其里。

大而顯者, 能有取焉。小而隱者, 能有取焉。

The gentleman gathers the great achievements.

Being able to advance them is to be a gentleman. If one is unable to advance them each will stop in its territory.

Of the great and obvious, (the gentleman) is able to take from it.

Of the small and concealed, (the gentleman) is able to take from it. ${ }^{30}$

The gentleman is defined as one who is able to "advance" (jin 進) the conducts that would otherwise remain separate from one another in order to obtain the harmony of goodness that is referred to as "the great achievements". This is clarified by the

28 Strip 18.

29 Mark Csikszentmihalyi offers a largely compatible reading of this passage, but argues that the practice of virtue is an "ideal of perfection" rather than a step removed from the sage (Csikszentmihalyi 2004, 80-81). Scott Cook suggests that the endlessness of virtue may also relate to its effects upon society (Cook 2012, 498 n.80).

30 Strips 42-44. I have followed Mark Csikszentmihalyi's reading of da cheng 大成 (Csikszentmihalyi 2004, 180-1). Despite this I have largely concurred with Scott Cook's reading for the remainder of the passage, such as taking the zhi 之 as referring to the conducts (Cook 2012,515-6). 
phrases "great and obvious" (da er xianzhe 大而顯者) and "small and concealed" (xiao er yinzhe 小而隱者). Though the wording is not identical, these phrases paraphrase the two passages describing the interaction of benevolence and righteousness that immediately precede this section and provide examples of how the gentleman takes from each of the conducts' domains. ${ }^{31}$

As for the enigmatic method of "advancing" the various conducts, the text provides a gloss ${ }^{32}$ for the term in a subsequent passage:

目而知之, 謂之進之。喻而知之, 謂之進之。 譬而知之, 謂之進之。幾而知之, 天也。

To know it by categorical comparison is referred to as "advancing it".

To know it by analogy is referred to as "advancing it".

To know it by metaphor is referred to as "advancing it".

To know it by intuition is Heaven. ${ }^{33}$

This section, which immediately follows the passage detailing the unifying power of the heart-mind, defines "advancing it" as three ways of understanding the world. The placement of these passages, together with the terms themselves, suggests that the first three methods are all functions of the heart-mind and, therefore, inherently human ways of understanding the world. The passage underscores this by distinguishing them from a Heavenly means of understanding objects through "intuition" ( $j i$ 幾). It is unclear if humans are able to access this method of understanding, although the possibility that Heaven is the subject of the final clause would seem to make it an unlikely prospect. Regardless, it is clear that the gentleman of goodness only utilizes human methods of understanding to assemble the disparate conducts into the harmony of goodness - reflecting the idea that an incomplete harmony is inherent to humans.

The text builds on the notion of "advancing" in the second half of the passage:

赫矑矑達諸君子道, 謂之賢。

君子，知而舉之，謂之尊賢;

知而事之，謂之尊賢者也;

後, 士之尊賢者也。

31 These occur in the aforementioned discussion of judicial conduct on strips 37-42.

32 Ikeda Tomohisa provides a somewhat similar interpretation of this passage (Ikeda 2003, 469).

33 Strips 47-48. I have followed Scott Cook in translating $m u$ 目 and $j i$ 幾, though I would diverge from Cook's interpretation by arguing that Heaven, not the gentleman, is the likely subject of the final clause. However, the phrasing is ambiguous and the translation tentative, though this does not seem to alter the overall point of the passage (Cook 2012, 518-9). 
One who gloriously and radiantly causes them to break through to the Way of the Gentleman, is referred to as "worthy".

As for the gentleman, to know and select him is referred to as "honouring the worthy."

Those who know of and serve him are referred to as "those who honour the worthy".

The latter are those scholars who honour the worthy.

Here, the text elaborates that it is not enough to advance the conducts; one must strive to elevate them to the Way of the Gentleman. Those who strive to reach this are suitable candidates to either employ or serve, reflecting the prioritization that the goodness section gives to active engagement with the world.

Therefore, the gentleman of goodness embodies some of the principal themes of the goodness section, such as worldly engagement, the idea that goodness is an inherent part of humans, and that one must strive for a higher state of being, as embodied by the gentleman of virtue:

\section{五行皆形于内而時行之, 謂之君 [子]。}

One for whom the five conducts all take form within and who enacts them in a timely manner is referred to as a gentleman. ${ }^{34}$

The gentleman of virtue is one who has developed all five conducts and is able to enact them in a timely, and therefore, virtuous manner. The gentleman of virtue is able to achieve this goal by further engaging in contemplation, exemplified by his concern with his "solitude" ( $d u$ 獨):

「淑人君子，其儀一也」。

能為一, 然後能為君子。

慎其獨也。

"The well-refined gentleman, his manner is singular".

Only if one is able to be singular can one be a gentleman.

(The gentleman is) cautious regarding his solitude. ${ }^{35}$

A greater focus on contemplation ${ }^{36}$ allows the gentleman to generate the fifth conduct of sagacity and thereby understand the Way of the Gentleman, which

34 Strips 6-7. The $z i$ 子 is missing due to a break in the strips (Cook 2012, 489 n.27).

35 Strips 17-18. I have followed Cook's excellent translation of this passage. The term "gentleman" is provided by the context of the following lines (Cook 2012, 496-7).

36 The gentleman of goodness would also engage in contemplation to develop the conduct of knowledge, but not to the same degree as he lacks sagacity. 
is the path to a successful and timely harmonization of the five conducts. ${ }^{37}$ This understanding sets the gentleman apart from those varied individuals described in the final passage of the goodness section, who simply hear and react to the Way without understanding it. Like King Wen, the gentleman of virtue is a singular figure who stands as the end goal of the process of self-cultivation. He understands and follows the Way of the Gentleman, and is thereby able to emulate Heaven by achieving a unified, timely and harmonious state among the conducts. Thus, while the text contrasts the Way of Humans and the Way of Heaven in its opening passages, the Way of Heaven is ultimately depicted as unreachable, and following the Way of the Gentleman is revealed as the true goal of the Wu Xing.

\section{Conclusion}

Focused on a truncated selection of mirroring passages, this study is necessarily limited and there remain many areas of future research that are likely to involve other texts and debates about early China. However, before the Wu Xing can be compared to other works it must be understood, as much as possible, on its own terms in order to fully appreciate both its own depth and the depth of its relationship to broader themes in early Chinese thought.

\section{References}

Chen, Lai. 2012. "Arguing for Zisi and Mencius as the Respective Authors of the 'Wuxing' Canon and Commentary Sections, and the Historical Significance of the Discovery of the Guodian 'Wuxing'Text." Contemporary Chinese Thought 43 (2): 14-25. Accessed August 9, 2016. http://dx.doi.org/10.2753/ CSP1097-1467430202.

Cheng, Chung-ying. 2010. "On Internal Onto-Genesis of Virtuous Actions in the Wu Xing Pian." Journal of Chinese Philosophy Supplement to Volume 37: 142-58. Accessed August 9, 2016. doi: 10.1111/j.1540-6253.2010.01616.x.

Cook, Scott. 2000. “Consummate Artistry and Moral Virtuosity: The 'Wu xing 五 行' Essay and Its Aesthetic Implications.” Chinese Literature: Essays, Articles, Reviews (CLEAR) 22: 113-46. Accessed August 4, 2016. http://www.jstor. org/stable/3109445. .

- 2012. The Bamboo Texts of Guodian: A Study and Complete Translation, Volume 1-2. Ithaca, NY: Cornell University East Asia Program.

37 This term is never clearly defined, although Kenneth Holloway argues that it may refer to the language used to teach self-cultivation (Holloway 2009, 55-58). 
Csikszentmihalyi, Mark. 2004. Material Virtue: Ethics and the Body in Early China. Leiden: Brill.

Holloway, Kenneth W. 2009. Guodian: The Nerwly Discovered Seeds of Chinese Religious and Political Philosophy. Oxford: Oxford University Press.

Ikeda, Tomohisa 池田知久, ed. 2003. “Kakuten Sokan 'Gogyō' no Kenkyū 郭 店楚簡五行の研究 (A Study of the Wu Xing of the Chu Strips of Guodian).” In Kakuten Sokan Jukyō Kenkyū 郭店楚簡儒教研究 (A Study of Confucian Teachings of the Chu Strips of Guodian), 451-80. Tokyo: Kyuko-Shoin Company.

Jingmenshi Bowuguan 荊門市博物館 (The Jingmen City Museum). 1998. Guodian Chumu Zhujian 郭店楚墓竹簡 (The Bamboo Strips of the Chu Tomb of Guodian). Beijing: Wenwu.

Li, Jiawu 李加武. 2015. “Guodian Chujian Wuxing Tianren Guanxi Yanjiu 郭店 楚《五行》天人關係研究 (A Study of the Relationship between Heaven and Humans in the Wu Xing of the Chu Strips of Guodian)." Wuling Xuekan 武陵學刊 (Wuling Journal) 40 (2): 17-22. Accessed August 10, 2016. doi:10.16514/j.cnki.cn43-1506/c.2015.02.004.

Li, Xueqin 李學勤. 1998. “Jingmen Guodian Chujian zhong de Zisizi 荊門郭 店楚簡中的《子思子》 (The Zisizi within the Chu Strips of Guodian, Jingmen)." Wenwu Tiandi 文物天地 (Heritage World) 2: 47-51.

Meyer, Dirk. 2012. Philosophy on Bamboo: Text and the Production of Meaning in Early China. Leiden: Brill.

Pang, $\mathrm{Pu}$ 龐樸. 1998. "Kong Meng zhi Jian: Guodian Chujian de Sixiangshi Diwei 孔孟之間 - 郭店楚簡的思想史地位 (Between Confucius and Mencius: the Intellectual Historical Position of the Chu Strips of Guodian)." Zhongguo Shehui Kexue 中國社會科學 (Chinese Social Sciences) 5: 88-95.

- 2000. Zhu Bo 'Wu Xing' Pian Xiaozhu ji Yanjiue 竹帛《五行》篇校注 及研究 (A Revision, Commentary and Study of the Bamboo and Silk Wu Xing Manuscripts). Taibei: Wanjuanlou Tushu LLC.

Perkins, Franklin. 2014. "Five Conducts (Wu Xing 五行) and the Grounding of Virtue.” Journal of Chinese Philosophy 41 (3-4): 503-20. Accessed August 8, 2016. doi: 10.1111/1540-6253.1212.

Puett, Michael. 2010. "Theodicies of Discontinuity: Domesticating Energies and Dispositions in Early China." Journal of Chinese Philosophy, Supplement to Volume 37: 51-66. Accessed August 2, 2016. doi: 10.1111/j.1540-6253.2010.01619.x.

Slingerland, Edward. 2008. "The Problem of Moral Spontaneity in the Guodian Corpus." Dao: A Journal of Comparative Philosophy 7 (3): 237-56. Accessed July 20, 2016. doi: 10.1007/s11712-008-9066-9. 
Wang, Miquan. 2016. “The Meaning of Xing 形 and Moral Transformation in Wuxing." Frontiers of Philosophy in China 11 (2): 222-35. Accessed August 30, 2016. doi: 10.3868/s030-005-016-0017-3.

Wang, Qinling 王沁凌. 2015. “Guodian Chujian 'Wu Xing' Sixiang Qianyi 郭店 楚簡《五行》思想淺議 (The Main Thoughts of the Wu Xing of the Chu Strips of Guodian).” Wuling Xuekan 武陵學刊 (Wuling Journal) 40 (2): 8-16. Accessed August 7, 2016. DOI:10.16514/j.cnki.cn43-1506/c.2015.02.003. 